\title{
Effects of Economic Crisis on International Circulators to Hungary
}

\author{
Sándor Illés ${ }^{1, *}$, Áron Kincses ${ }^{2}$ \\ ${ }^{1}$ Mobility and Migration Research Group, Active Society Foundation, H-1094 Budapest, Liliom u. 8, Hungary \\ ${ }^{2}$ Hungarian Central Statistical Office, H-1024 Budapest, Keleti Károly u. 2-4, Hungary
}

Copyright $@ 2018$ by authors, all rights reserved. Authors agree that this article remains permanently open access under the terms of the Creative Commons Attribution License 4.0 International License

\begin{abstract}
Circular mobilities have become frequent during the era of globalisation. This contribution provides empirical evidence relevant to the long-term international circular migrants admitted into Hungary in economic crisis period 2009-2012 in comparison with before decline of 2006-2008. The principal aim of this paper is to quantify some socio-demographic effects of economic crisis on the international circulators. Initially, we define the circulation within the conceptual framework between the continuum of transnationalism and translocalism. This is achieved by performing the critical literature review on definitions of circulation followed by the international migration and economic contexts. Then we analyse macro-scale data set on long-term international circular migrants based on an original statistical method. In the light of absolute and relative indicators we study changes in time series of circulators in comparison with first immigrants as reference group. We seek to gain insight into the change of socio-demographic composition of international circulators by gender, age and family status. We embed the empirical results into the recent migratory context and try to find possible explanations and interpretations of the effects measured. Lastly, we guess a new characteristic of multiple movers, namely international circulators are partially resistant to some negative effects of economic crisis.
\end{abstract}

Keywords International Migration, Circular Migration, Socio-demographic Effect, Economic Crisis, Hungary

\section{Introduction}

Based on the traditional view, migration is a single, i.e., non-repeating event. The settler type migration is considered an exceptional event within the individual life cycle. A single immigration may mean a migration (from the country of origin to the host country), a return migration (from the host country to the country of origin) or and onward migration (from the host country to a third country) $[33,37]$. The steps of the process are strictly separated from each other [61]. From the socio-demographic point of view, circulation consists of repeatable migratory moves, and the study of its parity (the number of times that a given individual migrates to a destination and back to home) is a problem that can be solved from the creation of biographical data sets, through the utilization of life course analysis and event history analysis with multi-sited approaches [6]. In migration studies, these terms, mobility and circulation are both old and new [47, 57]. Circulation involves a system of multiple, recurring spatial movements of individuals. The multiple moves of individuals interconnect two or more geographical locations $[29,4,9]$. The gross volume of international circular migration has undoubtedly increased. Many new types of circulators have begun to develop from repetitive tourists via commuters through migrants in the spatial mobility spectrum. Studies conducted worldwide found that the highly changeable character of circulation was the only consistent feature of the system [13, 14, 46].

Scholars investigated circulation in historical papers strong correlation with the urbanization in recent developed countries [56]. Later in the second half of the XXth century circulation research concentrated on labour systems and urbanization in the poor countries [17]. In Europe the most recent popularity of circulation may come from the activity of European Commission. The clerks conceptualise circulation as a triple-win solution about international brain-drain [60]. So, circulation becomes a catchword in international political and scientific circles $[51,58,3]$.

Several phenomena involving multiplicity accompanied the more frequent recurring spatial movements in the era of globalisation. These phenomena included multiple residence, multiple citizenship, multiple property ownership, multiple employment and multi-occupationality, multiple social and political activities, multiple identity [45], multiple knowledge, multiple loyalty and multiple partnerships (family, friendly, marital). We are aware that this list was not complete. 
Naturally, we could expand the roster [31 p.3.]. However, we only cited those newly emerging multiple phenomena that might exhibit a close relationship with circulation as a migratory system [16, 30, 34, 41, 52].

The simplest migration system consists of at least two elements. Return migration, typical of this pattern, inevitably includes the preceding migration [12, 13]. If the migrant explores more than one new country, we have a case of onward migration [2]. For a sophisticated concept of circulatory spatial movements, we develop the necessary elements of the phenomenon of circulation from the point of view of migratory systems. The migration system is no more than the sum of the migration processes, i.e., a set of non-independent associated moves. The most frequent example of circular system is the two-centre system. In this system, the flows occur between the two centres. In this case, the first movement is immigration to country of destination with parity number 1 . The return movement to the country of origin is no more than a simple return migration with parity number 2. However, the next immigration of the same individual to the same receiving country has parity number 3 . This third movement (step) is conceptualised as first-parity return to the country of immigration is sufficient for the occurrence of circulation and is irrespective of the particular residences involved.

The paper is organized as follows. We begin by discussing the heterogenous literature on the conceptualization of circulation what follows in Section 2 is the working definitions of international circular immigration. These definitions fit for the United Nation criteria. Section 3 enters the statistical arena of international migration in Hungary and compares the census and register sources. Then we explain the context of economic crisis put special emphasis on national peculiarities. In section 5 we turn to the core parts of the paper where we depict the data under investigation and the research method. In section 6 we analyse the gender, age and family status characteristics of circulators with the utilization of multidimensional tables. The article ends with a conclusion and discussion section.

\section{Literature Review on the Definitions of Circulation}

Because few circular movements are documented quantitatively, data gathering is essential [20, 25, 30, 43, 46, 47, 53, 65]. The present study aims to enrich our knowledge of circulation within an international migration context. Because we focus on Hungary as a receiving country, we concentrate on inwards circulation. Naturally, Hungary is an individual case and may represent an exception. Nevertheless, its statistical system allows us to create a unique macro-level database on international circular migrants. Following the initial study came from the author of this article [67], two additional papers addressed international circulation in reference to Hungary in 2010 and 2011.

The first paper was a report prepared by the official Hungarian branch of European Migration Network. The author defined circular migration as legal mobility involving movement back and forth between two countries regardless of the length of stay [66 p. 7]. However, she restricted the scope of circulation to labour migration, and her empirical examples (e.g., seasonal workers, researchers and students) relied only on simple migration processes. The movements presented in her paper lacked any characteristics of circular mobilities.

The second paper had an unfinished character and was part of the broader Metoikos research project on circular migration patterns in Southern and Central Eastern Europe. The authors concentrated on field work in the Ukrainian-Hungarian border region and sought to describe different migratory and circulatory patterns [10]). Their descriptions relied primarily on their own qualitative research. The interviewees described their migration-related experiences, but the respondents were mainly international commuters rather than circular migrants. Six main types of legal circular migration (more precisely mobility) were distinguished by the authors based on an unknown number of interviews. Unfortunately, those authors neglected the large amount of Hungarian and Ukrainian literature highly relevant to this topic and failed to recognise the scope of circular human mobilities [35, 36, 54]. Accordingly, we disputed the validity of their results on international circular migrants between Ukraine and Hungary. In that study, the term "circulation" was used as a popular commercial label to manage the project for bureaucratic purposes.

The definition of circulation is one of the key questions that our contribution will address [59, 62]. For an explicit definition fitted for statistical purposes, we will select international circular migrants from the mass of international migrants. We formulate a definition of circulation suited to our specific aims to explore the demographic structure of circulators. To fulfil these aims we review the recent literature on this topic.

Circulation is not an entirely novel idea in the contemporary literature $[20,53,60]$. According to the widely quoted study of Wilbur Zelinsky [63 p. 226], "Circulation denotes a great variety of movements, usually short term, repetitive, or cyclical in nature, but all having in common the lack of any declared intention of a permanent or long-lasting change in residence." In his essay, Frank Bovenkerk [8 p. 5] defined circulation from the perspective of the country of departure as "the to and fro movement between two places, (this movement) includes more than one return (to the place of origin)." The same definition would be valid, with little modification, from the perspective of the country of destination. The Bovenkerk's definition conceptualises the spatial system from inward perspective. But the same flows could be investigated from outward angle, too. In 
their introductory paper, Murray Chapman and R. Mansell Prothero [17 p. 1] recognised that "the reciprocal flows, called circulation, which involve the interchange of individuals and small groups between places (origins and destinations) that frequently are of differing size and function, such as villages and towns or regional centres and primate cities.”. The authors stressed the reciprocal character of flows, however, they restricted returns only one home and lots of destinations. Another more recent recognition of circulation involves different aspects of migration: "Circular migration is a continuing, long-term, and fluid pattern of international mobility of people among countries that occupy what is now increasingly recognised as a single economic space.” [46 p. 1].

We address the central concern of this study on the returns to the destination country (Hungary). In general, in a system including only two countries, the return to the country of immigration is the next step taken by individual circulators in terms of the serial number after he or she returns to the country of origin. In reality, circular migration cannot be limited to a binary, pendulum-like movement between two countries [14]. Flows with a circular character might occur among three or more countries as well. The most recent attempt to define circulation for a purpose similar that of our research began more one decade ago [32] originated from a supranational organisation. Note that an acceptable definition of circulation has not been formulated by any EU member states. As a result, the Janus-faced process of coordination under the umbrella of the European Migration Network, the following definition has emerged: Circulation is nothing other than "a repetition of legal migration by the same person between two or more countries" [ 25 p. 14].

In summary, the general definition of circulation is as follows fitted for our qualitative, macro-statistical point of view: circulation is a type of spatial mobility system between two or more places containing at least three interlinked, individual movements in which at least one has return character - from inward perspective [31 p. 42]. We intentionally use the broadest concepts applicable to human movements, such as "spatial mobility system" and "movement", to allow a more workable conceptualisation of the notion of circulation with additional connotations of tourism, commuting and migration $[49,55]$. The concept usually involves return and repetition. For the specific purpose of this research, we create a particular definition. The exact definition of international circular migration for the creation of macro-statistics is as follows: international circular migration is a type of spatial migratory system between two or more places including at least three interlinked, individual migrations in which at least one has return character among the countries involved - from inward perspective [31 p. 42]. According to this definition, international circular migration constitutes multiple return moves within the same spatial system - from mixed (inward and outward) perspectives. We might differentiate between non-national circulars residing in the country of origin (inwards circulation) and non-national circulars settled in the host country (outwards circulation). We may combine the inward and outward perspectives and study the circulation together. However, by analogy to the distinction stated by the European Commission [25 p. 14], we prefer inward to outward angle. From methodological point of view, the analytical value of these two perspectives is equivalent. For practical reasons, due to data accessibility of foreigners we decided to utilise the inward perspective in Hungarian case study.

\section{Economic Crisis in Hungary}

According to the historical experiences related to economic crises in the twentieth century, the scholars with different scientific background anticipated with high probability the elements of the short-term migratory effects of downturn started 2008 were as follows.

- Less new immigrants arrived in receiving countries [10, 11, 15, 22, 42, 50].

- Return flows increased to home countries [27, 64].

- Remittances decreased due to the rise of unemployment amongst immigrants $[7,18,48]$.

These short-term consequences of global economic decline worked in the interlinked developed countries generally but in an uneven way from regional perspective. The economic recession caused a larger decline in post-socialist Europe than any other region in the world [19]. This was a heterogeneous spatial group in which Hungary, a small country with open economy, suffered a deeper and longer falling period 2008-2011. The macro-economic nature of the crisis was similar to the other East and Central European countries: decline in GDP, per capita income and growth in unemployment rate [26]. It started as financial crisis that enlarged severe economic and social ones mainly in micro-level due to the predatory lending to private actors (people), just as any part of the world [1]. With the growth reversal, the credit-fuelled expansion erected from foreign savings ended in inner consumption and investment [19]. Moreover, as results of the crisis the sock of private and public debts increased sharply in the edge of crisis in Hungary in 2011 parallel to the decline of export-oriented industrial production [38]. So the financial crisis escalated into other sectors of the economy, decreased the household real incomes and increased the vulnerability of the society. Relative regional position of the country worsened in East and Central Europe. The migrants' attraction force of the country lagged behind the European Union countries competing for immigrants.

One of the main spectacular consequences of the crisis deep devaluation of Hungarian currency, forint (HUF), happened [23]. However, this process caused the increase one element of territorial in-mobility spectrum. Namely, the number of daily visitors (tourists) arriving to Hungary 
with shopping motivation from neighbouring eurozone member states increased dynamically during the period of the crisis [44].

From speculative way, the immediate economic consequences hit mainly economically active male immigrants in construction and manufacturing as individuals. Non-economic actors with immigration background just as guest-workers' family members, students and retired people suffered smaller extent of the crisis effect [16 p. 200]. We can also distinguish first immigrants from circulators in the next sections. There are many differences between two groups. For instance, circulators possessed more migration-specific capital about the Hungarian circumstances. Whether did this fact function as an advantage in crisis period due to the multiple self-selection processes presented in literature $[40,61]$ ? If yes, circulators would be positively selected, but how many times and what extent? Whether the growing share of circulators could be one of the indicators of this positive self-selection phenomenon? However, there was no precedent in the recent crisis literature to differentiate long-term circulators from first immigrants and investigate any circulators' specific consequences of decline interval. In this case study we would like to contribute to fill this gap.

\section{Materials and Methods}

The current study's empirical analysis of international circular migrants was limited to Hungarian immigration data. This choice had several advantages. The data set came from a comprehensive administrative database. The method of data gathering harmonised well with international recommendations. In this study, we concentrate on the aspects of multiple movers related to immigration. As a reference group, of course, we can also distinguish the first-parity immigrants. In our subjective opinion, which may be open to dispute, the main value of this research is that we could distinguish the international circular migrants within the overall complexity of immigration patterns. In addition, we explored particular aspect of the demographic and territorial patterns shown by the international circular immigrant population in Hungary.

The main disadvantage of this research is its country-dependency. The Hungarian case study occupied the centre of our perspective. The study did not include emigrants from Hungary. From this perspective, we could only distinguish immigrants by parity. For example, we could distinguish those that arrived in the country for the first time, for the second time and for the third time. We did not have precise information about the destination of immigrants who left Hungary between their two stays in the country, i.e., whether such migrants returned to their country of citizenship or emigrated to a third country.
In this paper, first, we utilized the critical review of most recent literature, legislations and policy documents. The interpretation of human circulation is one of the key questions that our research will address due to circulation is not an entirely novel idea in the contemporary literature. Clearly given the macro-scope of this research, second, we use time series analysis and demographic table methods combined with parity analysis. Third, the age pyramids serve the visualisation, as classic method of population studies.

In general circulation was a system of multiple spatial moves of individuals with return character - depicted in the 2. Chapter. We followed that, in particular, from the angle of this research, circulators were return foreign immigrants to Hungary. Immigrants at first are not circulators but they serve as a useful reference group for the in-depth analysis besides of all immigrants. People who receive immigrant status twice-three-four times and so on are only circulators. The data below originate from the continuous registration system of Immigration and Nationality Office. In the absence of personal identifier number, we utilized a special computer programme [31] in order to distinguish circulators as the subject of this paper year by year from 2006 through 2012. This contribution provides empirical evidence in crisis period 2009-2012. The economic recession may cause decrease in mobility flows in many receiving countries. The principal aim of this paper is to quantify the potential effects of economic crisis on the international circular migration in comparison with before crisis period of 2006-2008.

We suppose that the effects of economic crisis were embedded on the differences in indicators between two periods. We are aware of that structural changes and the consequences of other forces played role in the development of differences. However, according to a literature signal [20] the effect of economic crisis had the biggest macro-effect on international migration in general Europe and in particular Hungary from 2009 to 2012. Moreover, the changes in structures year by year were partly eliminated by the addition of before crisis and downturn years. In the light of these methodological shortcomings, we analyse the differences with high caution and only highlight robust results with their potential explanations.

\section{Results: Differences amongst Socio-demographic Indicators}

169871 foreign immigrants arrived to Hungary between 2006 and 2012. Of these immigrants, 25268 have already stayed in Hungary as immigrant status. These facts indicate that 14.9 per cent of these immigrants were long-term circulators (multiple returnees) with previous personal experience with the country. International migration as a process is very sensible to economic, social, political and 
natural changes, too. If we distinguish average values between before crisis period (14.7\%) and crisis period (15.1\%) we may conclude that due to the effect of crisis the frequency of circular immigration remained relatively stable or in other words increased slightly that is unexpected in many levels.

All in all, the average yearly number of first immigrants was 22205 people in before crisis period and 19490 people in crisis period. The average yearly number of circulators was 3636 people in before crisis period and 3590 people in crisis period. The average decrease was smaller amongst circulators, so the intensity/probability of circulation grew from $14.7 \%$ to $15.1 \%$ in the context of first immigration.

We must mention that the probabilities changed in the result of complex interplay amongst immigration figures, emigration figures and status modification (in which acquiring Hungarian citizenship dominated). The separation of the effect mentioned above is out of the scope of this paper.

The time series of immigrants and circulators reflect the highly changeable character of spatial movements. The volumes of international migrant grew before crises period significantly in parallel with the increase of the absolute numbers of circular immigrant. However, the intensity of growth of circulators was smaller so the share of circulators declined between 2006-2008. According to the predictions of relevant literature cited above the number of immigrants decreased continuously during the crisis period. But the volumes of circulators remained stable between 2009-2010. Due to the opposite change in numbers of immigrants and circulators the share of circulators rose sharply between 2008-2010. New citizenship law was introduced in 2011 in which gaining citizenship was simpler for ethnic Hungarians living near borderline mainly in Romania, Ukraine and Serbia [28, 54]. Due to the new legal rules lots of real and potential immigrants and circulators became Hungarian citizen (the status improvement from alien to citizen was the rational individual choice among ethnic Hungarians) so this status change diminished the probability of becoming immigrants and circulators in Hungary from inward perspective. In the second stage of crisis period (2011-2012) both the volumes of immigrants and circular immigrants decreased continuously hand in hand in the share of circulators. We may suppose that the yearly shares of circulators would not have been decreasing since 2011 if the new citizenship provisions had not been introduced. The growing shares of circulators in 2009-2010 echoed the increasing frequencies of circulators in the context of economic crisis.

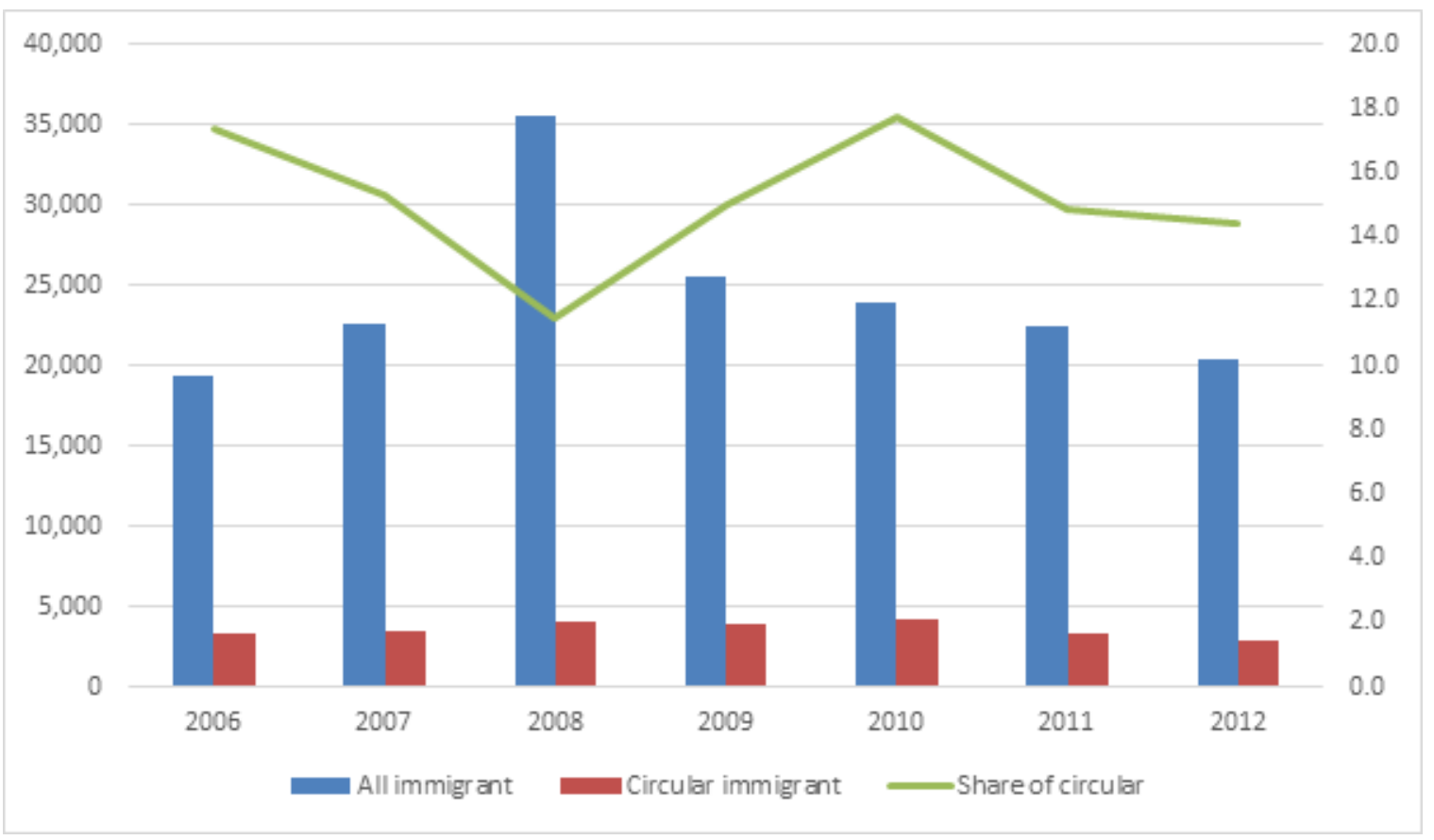

Figure 1. Number of international immigrants, international circular immigrants and the share of circulators in Hungary from 2006 to 2012 


\subsection{Gender Dimension}

56.9 per cent of the total number of immigrants was men, 43.1 per cent women. Among the circular migrants, 56.2 per cent were men, 43.8 per cent women. We can conclude that a massive male surplus exists among the circular migrants just as all immigrants. However, the probability that an international migrant woman becomes a circular migrant is higher (plus 0.7 percentage point) than the corresponding value for a man (minus 0.7 percentage point) for the whole period investigated in Hungary. At first sight this finding may contradict the cultural truism that often opposes mobile masculinity to localised femininity. From a gender perspective, the higher female probability of becoming a circular migrant would represent one of the symptoms of the feminisation process within international migration and would indicate a weakening of the supremacy of economic motives. However, if we put the question that there are many differences between before crisis and crisis period the answers sophisticate the crude pictures ahead. In the before crisis period both the female difference (plus 1.9 percentage point) and the male difference (minus 1.9 percentage point) were higher than whole period. In times of trouble, the female positive difference became negative (minus 0.2 percentage point). The male difference modified to (minus 0.2 percentage point). These results were should be interpreted with caution due to the small differences. Moreover, we must stress that the force of cultural truism on mobile masculinity and localised femininity grow in the processes of immigration and circulation during the crisis period related to Hungary. From gender perspective the feminisation process of circulators worked in the peaceful before crisis period, but it disappeared during economic crisis mainly among economically active ages. Opposite of this finding the feminisation process of first immigrants appeared during crisis period mainly 0-19 years old age group and $50+$ age group.

Studying the sex differences in terms of absolute values we state that the average yearly number of first female immigrants was 9417 people in before crisis period and 8487 people in crisis period. The average yearly number of female circulators was 1621 people in before crisis period and 1553 people in times of economic downturn. The average yearly number of male circulators was 2015 people in before crisis period and 2037 people in times of trouble. We must emphasise that the average number of male circulators grew a little bit as the unexpected effect of economic crisis.

Table 2. Examining the gender differences in relative ways we stress that the share of first female immigrants was $42.4 \%$ in before crisis period and $43.5 \%$ in crisis period. The share of male circulators was $55.4 \%$ in good time periods and $56.7 \%$ in crisis period. We must emphasise that both the lesser base female first migrant value and the higher base male circulator value grew a little bit as the effect of economic crisis.

Table 1. International immigrants and international circular immigrants by gender in Hungary from 2006 to 2012, (\%)

\begin{tabular}{|c|c|c|c|c|c|c|c|c|c|}
\hline \multirow{2}{*}{ Year } & \multicolumn{4}{|c|}{ All immigrant } & \multicolumn{3}{c|}{ Circular immigrant } & \multicolumn{2}{c|}{ Firstly immigrant } \\
\cline { 2 - 10 } & Male & Female & Together & Male & Female & Together & Male & Female & Together \\
\hline 2006 & 55,2 & 44,8 & 100,0 & 54,2 & 45,8 & 100,0 & 55,4 & 44,6 & 100,0 \\
\hline 2007 & 56,4 & 43,6 & 100,0 & 55,0 & 45,0 & 100,0 & 56,7 & 43,3 & 100,0 \\
\hline 2008 & 59,0 & 41,0 & 100,0 & 56,8 & 43,2 & 100,0 & 59,3 & 40,7 & 100,0 \\
\hline 2009 & 57,0 & 43,0 & 100,0 & 56,1 & 43,9 & 100,0 & 57,2 & 42,8 & 100,0 \\
\hline 2010 & 56,3 & 43,7 & 100,0 & 57,5 & 42,5 & 100,0 & 56,0 & 44,0 & 100,0 \\
\hline 2011 & 55,9 & 44,1 & 100,0 & 56,7 & 43,3 & 100,0 & 55,7 & 44,3 & 100,0 \\
\hline 2012 & 56,8 & 43,2 & 100,0 & 56,6 & 43,4 & 100,0 & 56,8 & 43,2 & 100,0 \\
\hline $2006-2008$ & 57,3 & 42,7 & 100,0 & 55,4 & 44,6 & 100,0 & 57,6 & 42,4 & 100,0 \\
\hline $2009-2012$ & 56,5 & 43,5 & 100,0 & 56,7 & 43,3 & 100,0 & 56,5 & 43,5 & 100,0 \\
\hline $2006-2012$ & 56,9 & 43,1 & 100,0 & 56,2 & 43,8 & 100,0 & 57,0 & 43,0 & 100,0 \\
\hline
\end{tabular}




\subsection{Age Dimension}

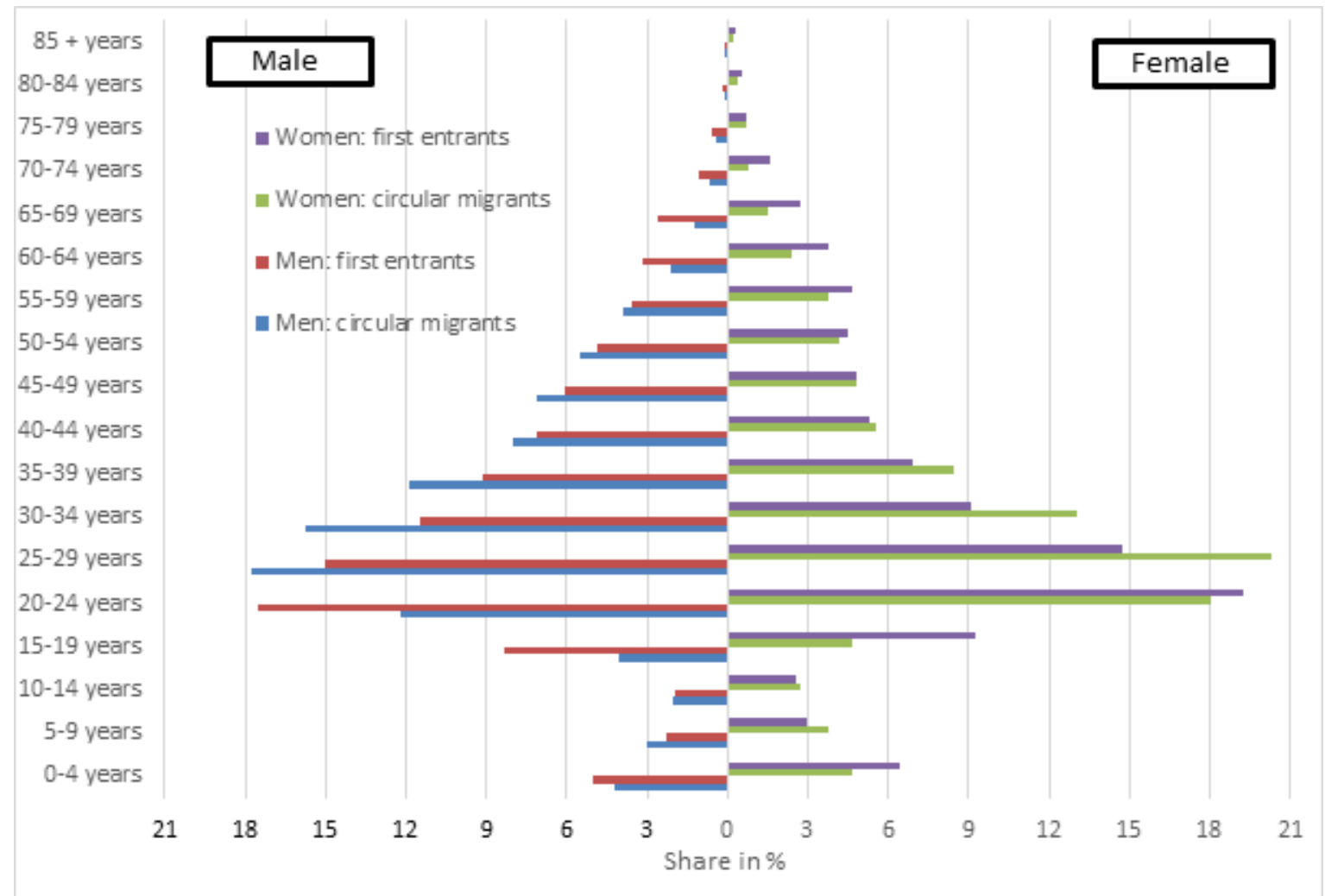

Figure 2. Age pyramid of first immigrants and circulators in Hungary between 2006 and 2008, (\%)

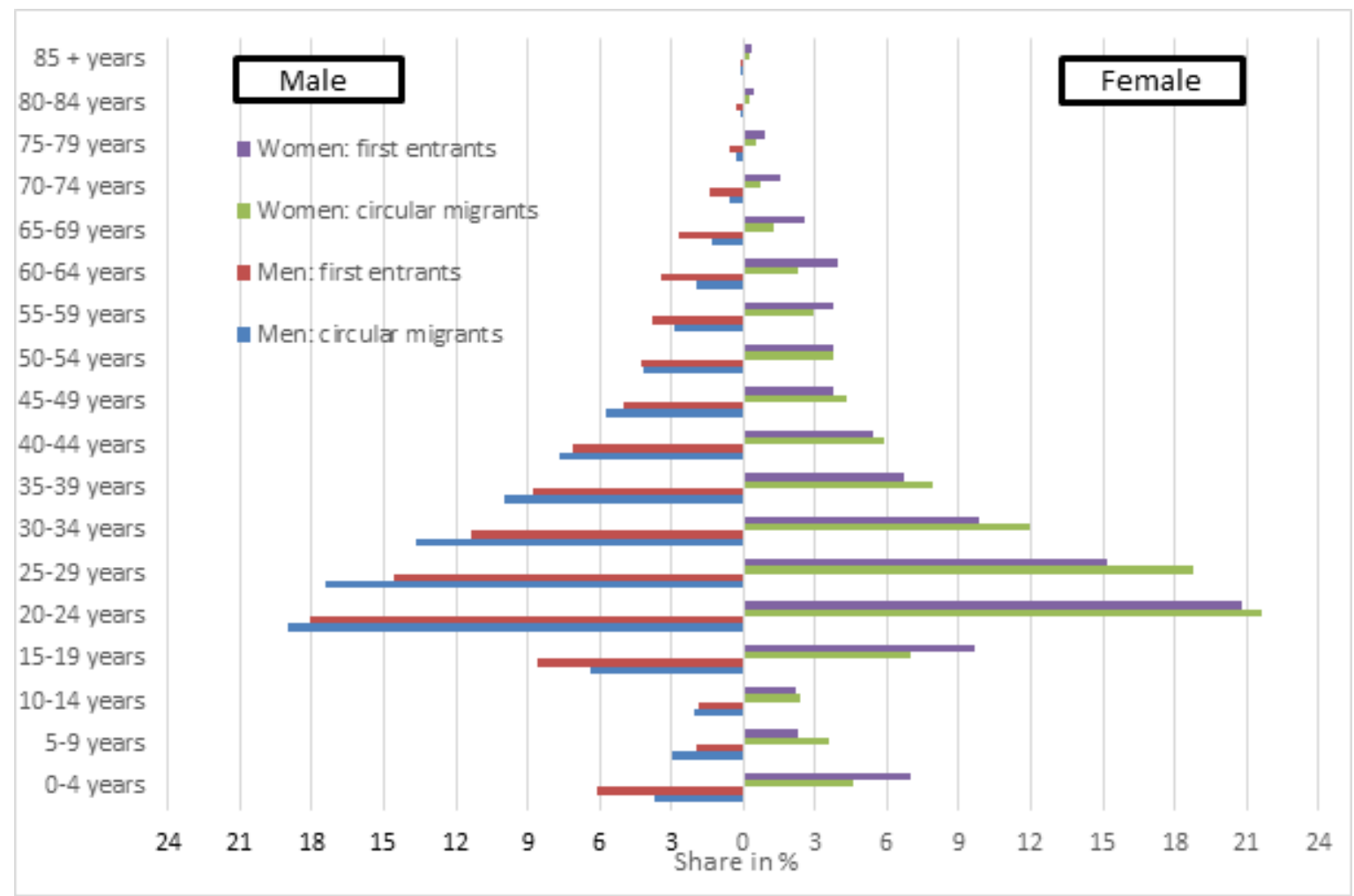

Figure 3. Age pyramid of first immigrants and circulators in Hungary between 2009 and 2012, (\%) 
After studying the sex and gender perspectives the age is an additional aspect of in-depth analysis. The investigation of the age composition of the subject matter (circulators) in comparison with first immigrants indicates that children (aged 0-4), secondary school students (aged 15-19) and retired people (aged 65 and up) were less frequent among the circular immigrants than first immigrants. The percentages of primary school pupils (aged 5-14), tertiary school students and first time job seekers (aged 20-24) in pair are equal among circular immigrants and all first time immigrants. The most frequent five-year age groups of circulators and first migrants are situated in the middle segment of age pyramid (aged 25-64). This forty-year age group was dominant with more than half of circulators and first immigrants. In which youths (aged 25-44) were more populous than elders (age 45-64).

Based on this structure we must say that labour mobility was the dominant source of international migration and international circular migration, too. Many migrants are involved in one or more circulatory systems (immigration-return-second immigration....). Accordingly, they simultaneously retained links to their country of origin by sending remittances, by conducting dual entrepreneurial activities and by moving back and forth. These activities reflect a dual attachment to the source country and the receiving country.

Moving back to the main aim of this paper, the elements of effect of economic crisis, in this paragraph we concentrate on the modification of age segments. Age structure of circulators modified a little bit in comparison with first immigrants (Figure 2-3). Firstly, among the 20-24 year olds significant change happened in 2009-2012. The share of circulators of both sexes became higher than first immigrants in crisis period. Secondly, within the 45-49 year-old females the share of circulators became higher than first immigrants in recession period. Thirdly, among the 50-59 year-old males the share of circulators became lower than first immigrants in crisis period. Finally, within the 75-79 year-old females the share of circulators became lower significantly than first immigrants in times of trouble. Based on these four findings we can conclude that the consequences of crisis in one hand the student type circulation were strengthened in combination with early job seeking circulation in both sexes. On the other hand late age job related circulation was diminished in both sexes parallel to the retirement mobilities.
Table 2. Average age of international non-circular (1) and circular (2X) immigrants by parity of entering in Hungary from 2006 to 2012 (both sex)

\begin{tabular}{|c|c|c|c|c|c|c|}
\hline \multirow{2}{*}{ Year } & \multicolumn{5}{|c|}{ Numbers of entering } & \multirow{2}{*}{ Total } \\
\cline { 2 - 6 } & 1 & 2 & 3 & $4-X$ & $2-X$ & \\
\hline 2006 & 31,0 & 32,4 & 29,5 & 33,7 & 31,8 & 31,2 \\
\hline 2007 & 32,4 & 29,0 & 31,3 & 31,7 & 29,6 & 32,0 \\
\hline 2008 & 32,7 & 34,0 & 33,8 & 32,3 & 33,9 & 32,9 \\
\hline 2009 & 33,4 & 32,7 & 33,3 & 34,6 & 33,5 & 33,3 \\
\hline 2010 & 33,3 & 30,1 & 30,7 & 33,5 & 31,0 & 32,9 \\
\hline 2011 & 33,4 & 31,5 & 31,3 & 33,3 & 31,8 & 33,2 \\
\hline 2012 & 31,7 & $\mathbf{3 0 , 4}$ & $\mathbf{3 0 , 2}$ & 32,5 & $\mathbf{3 0 , 9}$ & 31,6 \\
\hline $2006-2008$ & 32,0 & 31,8 & 31,5 & 32,6 & $\mathbf{3 1 , 8}$ & 32,0 \\
\hline $2009-2012$ & 33,0 & 31,2 & 31,4 & 33,5 & $\mathbf{3 1 , 8}$ & 32,8 \\
\hline $2006-2012$ & 32,6 & $\mathbf{3 1 , 4}$ & $\mathbf{3 1 , 4}$ & 33,1 & $\mathbf{3 1 , 8}$ & 32,5 \\
\hline
\end{tabular}

Turn now to another indicator of age composition (Table 3.). The average age of all immigrants was 32.5 years in 2006-2012. In the crisis period this value was higher (32.8 year) than before crisis period (32.0). The average age of circulators was 31.8 years and there was no change in two periods. The return was a subsequent stage after first immigration in the individual migratory life course. The individual returnee was indeed older than he/she had been first immigrant. Surprisingly, the subpopulation of circular immigrants was more youth than first immigrants. The average age of second and third immigrant circulators did not therefore rise according to parity except for fourth and more immigrant circulators in 2006-2012. Under the effect of slowdown the second and third immigrant circulators became more youth and the fourth and more immigrant circulators became older.

In addition, the female international migrants were younger, than their male counterparts (30.8 years and 34.5 years). In the crisis period these values were higher than before crisis period in both sexes. The circular immigrant females were younger than first immigrants $(30.2,33.8)$, but in the times of trouble the average age of female circulators did not change (30.2, 30.2). As a possible explanation of this stability, it is highly probable that the women began their immigration careers to Hungary earlier than the men, probably as students. 


\subsection{Family Status Dimension}

Table 3. Family status distribution of international non-circular (1) and circular (2-X) immigrants by parity of entering in Hungary between 2006 and 2008, (\%) (both sex)

\begin{tabular}{|c|c|c|c|c|c|c|}
\hline \multirow{2}{*}{ Family status } & \multicolumn{5}{|c|}{ Numbers of entering } & \multirow{2}{*}{ Total } \\
\cline { 2 - 6 } & 1 & 2 & 3 & 4 & $(2-X)$ & \\
\hline Single & $\mathbf{4 7 . 4}$ & 52.6 & 56.6 & 57.8 & $\mathbf{5 3 . 6}$ & 48.3 \\
\hline Married & 44.2 & 39.9 & 37.4 & 36.9 & 39.3 & 43.5 \\
\hline Widowed & 3.2 & 2.8 & 2.5 & 2.2 & 2.7 & 3.1 \\
\hline Divorced & 5.2 & 4.7 & 3.6 & 3.0 & 4.4 & 5.1 \\
\hline Total & 100.0 & 100.0 & 100.0 & 100.0 & 100.0 & 100.0 \\
\hline
\end{tabular}

Table 4. Family status distribution of international non-circular (1) and circular (2-X) immigrants by parity of entering in Hungary between 2009 and 2012, (\%) (both sex)

\begin{tabular}{|c|c|c|c|c|c|c|}
\hline \multirow{2}{*}{ Family status } & \multicolumn{5}{|c|}{ Numbers of entering } & \multirow{2}{*}{ Total } \\
\cline { 2 - 6 } & 1 & 2 & 3 & $4-X$ & $2-X$ & \\
\hline Single & $\mathbf{5 6 . 3}$ & 62,5 & 67,2 & 68,6 & $\mathbf{6 5 . 2}$ & 57,7 \\
\hline Married & 35,6 & 30,3 & 27,0 & 26,5 & 28,5 & 34,5 \\
\hline Widowed & 2,3 & 2,0 & 1,8 & 1,6 & 1,9 & 2,2 \\
\hline Divorced & 5,8 & 5,2 & 4,0 & 3,3 & 4,4 & 5,6 \\
\hline Total & 100,0 & 100,0 & 100,0 & 100,0 & 100,0 & 100,0 \\
\hline
\end{tabular}

Table 5. Family status distribution of international non-circular (1) and circular (2-X) immigrants by parity of entering and sex in Hungary between 2006 and 2012, (\%) (both sex)

\begin{tabular}{|c|c|c|c|c|c|c|}
\hline \multirow{2}{*}{$\begin{array}{c}\text { Family } \\
\text { status }\end{array}$} & \multicolumn{5}{|c|}{ Numbers of entering } & \multirow{2}{*}{ Total } \\
\cline { 2 - 6 } & 1 & 2 & 3 & $4-X$ & $2-X$ & \\
\hline Single & $\mathbf{5 2 . 2}$ & 57.2 & 62.7 & 68.1 & $\mathbf{6 0 . 2}$ & 53.4 \\
\hline Married & 39.6 & 35.5 & 31.5 & 26.9 & 33.2 & 38.6 \\
\hline Widowed & 2.7 & 2.4 & 2.0 & 1.7 & 2.2 & 2.6 \\
\hline Divorced & 5.5 & 4.9 & 3.8 & 3.3 & 4.4 & 5.3 \\
\hline Total & 100.0 & 100.0 & 100.0 & 100.0 & 100.0 & 100.0 \\
\hline
\end{tabular}

In the following analytical part, we continue the examination of structure with respect to family status. Single and married people had the most significant shares (53.4\%, 38.6\%) within all immigrants in 2006-2012. The shares of divorced and widowed immigrants were small significance $(5.3 \%, 2.6 \%)$. Perhaps one of the most interesting findings is that the percentage of single people (60.2 per cent) among the circular migrants is higher than that among the non-circulars (52.2 per cent). Several interesting facts are evident from these figures. One possible explanation is that the 'mobile' way of life is not typical of those who have legal partnerships, with or without children. In other words, the legally married status may not start or might end the circular career of individuals. The presence of immediate family members either in departure or destination may reduce the probability of circulation. This hypothesis strengthens Vertovec's [65 p. 1055-1056] speculation on the likelihood of circular migration: "Repeat movements are likeliest among young unmarried men; this likelihood falls with marriage, and increases again with children.” and Constant and Zimmermann's [21, p. 512] findings: "Those immigrants who are the most mobile and open to circular migration are the middle-aged, male, and single migrants".

However, we cannot state that the probability of circulation is higher for the people without legal partnership n general than for the people with partners [5]. This conclusion cannot be drawn due to the lower percentage of widowed and divorced circulars. Such findings are germane to arguments associated with the erosion of the traditional concept of the family and the creation of new types of cohabitation.

The effect of crisis was clear on the circulars' family status. The share of single people increased enormous way from $53.6 \%$ to $65.2 \%$ at a disadvantage of married (28.5\%) and widowed (1.9\%). The share of divorced individuals remained the same $(4.4 \%)$ in the times of trouble. These indicators strengthened the explanation ahead that the 'mobile' way of life is typical of those who are single people with or without children mainly in crisis period. In contrast, the recession cemented one or both members of married couple to the country of usual place of residence or tried to become the citizens of receiving country.

\section{Conclusion and Discussion}

In general circulation is a system of multiple spatial moves of individuals with return character. It means that opposite of common misunderstanding human circulation is not a form of migration. However, second parity immigration is a final step of a most simple international circular migration system. Before the second parity immigration to Hungary two steps happened. A return or onward international migration from Hungary and before that first parity immigration happened to Hungary by the same individual. In particular, from the angle of this research, circulators are return foreign immigrants to Hungary. We must stress again that first immigrants are not circulators. People who receive immigrant status twice-three-four times and so on are only long-term international circulators.

The data under investigation originate from the continuous registration system of Immigration and Nationality Office. In the absence of personal identifier number we created a special computer programme in order to distinguish circulators as the subject of this paper to first immigrants year by year from 2006 through 2012. This contribution concentrates on empirical evidences in crisis period 2009-2012 in order to explore the effect of economic crisis on the stocks of international circulators and analyse the socio-demographic structure of circulators.

In accordance with the literature signals immigration decreased in crisis period most of the developed countries. In Hungary there were slowdowns in first immigration and 
circular immigration in absolute term. However, the decrease of first immigrants was even more intense than circulators. As frequency matters, slight increase of circulators happened from $14.7 \%$ to $15.1 \%$. So circular immigration remained relatively stable that was unexpected in many angles. We might explain this growth with strong migration specific capital and knowledge gathered by previous and recent immigrations of circulators at first glance. However, rigorous and systematic research steps are needed to distinguish potential explanations and interpretations to our more or less subjective conjectures.

There was slowdown in all immigrants (first immigration and circular immigration) during crises period in absolute terms. Relation to recent literature: this finding is in corroboration with Czaika [22], Çağlar [10, 11], Zimmermann and Zaiceva [64], Castles [15], McCollum and Findlay [42]. However, the decrease of first immigrants was even more intense than circulators. In the consequence of these processes slight increase measured about circulators. Their share increased from $14.7 \%$ to $15.1 \%$ within all immigrants. Potential structural (inner) explanation: The probability of status change was higher for first immigrants than circulators due to the more gain in comparison with the cost of return or becoming circulator (this is more probable after 2011 under the effect of new citizenship law). Potential outer interpretation: The first immigrants are vulnerable group than circulators due to their less migration specific capital. Our general conjecture: The resistance against economic crisis is stronger among circulators than first immigrants. If we add to this guess that all immigrants were more educated and economically active according to the 2011 census the group of circulators could be measured that a valuable part of Hungarian society.

Male dominance was measured during all periods investigated. This fact is in line with the literature of international circular migration [20, 53, 60, 65]. However, the male surplus increased a little bit from $55.4 \%$ to $56.7 \%$ within circulators (Table 1). Potential structural (inner) explanation: The probability of status change was higher for female circulators than male circulators. Potential outer interpretation: Female circulators are more vulnerable group than male circulators due to their less average age of international circulations. Our general guess: The period of economic prosperity is relatively more advantageous for female immigrants. In opposite of this economic decline worsens the female labour market position than male counterpart. The resistance against the negative effects economic crisis (unemployment, emigration) are stronger among male circulators than female circulators.

The average age remained the same: 31.8 year and 31.8 year within circulators (Table 3). No effect was measured. The age structure of circulators modified a little bit more in comparison with first immigrants: Potential structural (inner) explanation: a) within the 20-24 year-old all immigrants the share of circulators of both sexes became higher than first immigrants in crisis period. b) Within the 45-49 year-old female immigrants the share of circulators became higher than first female immigrants in crisis period. c) Within the 50-59 year-old male immigrants the share of circulators became lower than first male immigrants in crisis period. d) Within the 75-79 year-old female immigrants the share of circulators became lower significantly than first female immigrants in crisis period (Figure 2-3). Potential outer interpretation: non-economic forces function at female 75-79 age group, mixed (non-economic and economic) forces work at 20-24 age groups. Our general conjecture: single international student immigrants were hit lower than married young workers at 20-24 age group, widower family status induces the first immigration to Hungary closer to their family members or life in institution started at female 75-79 age group.

The single dominate among all immigrants to Hungary in 2006-2012. This evidence completely conforms with the research results on international immigration [5, 24, 61].

The proportion of single people is higher in circulators (60.2\%) than first immigrants (52.2\%). Relation to recent literature: this finding is in corroboration with Vertovec [60, 65], Skeldon [53], Constant and co-authors [20], Constant and Zimmerman [21], Weber and Saarela [61].

The share of single circulators increased in an unexpected way from $53.6 \%$ through $65.2 \%$ in crises period (Table 4-6). This is the most robust socio-demographic result of the research. Potential structural (inner) explanation: a) Single peoples inherently are the youngest and most mobile amongst the forms of family status. b) The probability of status change from immigrant to Hungarian citizen is higher for married circulators than single circulators due to the more gain in receiving country in comparison with the cost of return to sending country. c) Single circulators are less vulnerable because of the absence of obligations come from the legal status and/or due to intergenerational transfer flowed from parents to children (the new citizenship law in 2011) was not so attractive for young sing people with high potential of mobilities). Potential outer interpretation: the single first immigrants are vulnerable group than single circulators due to their less migration specific capital (return or onward options are probable for single first immigrants than single circulators). All forms of capital are cumulated by single circulators are higher than single first immigrants. In one hand single circulators were protected by one portion of these capitals on the other hand single circulators guard the other portion of own capitals during crisis period. So, return or onward options are less probable for single circulators than remain option in receiving country during period of trouble. Our general guess: Resistance against economic crisis is higher international circulators than first time immigrants. The 
phenomenon of crisis resistance is extremely valid for single international circulators in Hungary.

We are aware of these new findings relate only to Hungary according to this case study. However, we guess that the validity of crisis resistance of circulators is more general. Whether the circulators are going to become the object of proactive international migration policies based on empirical evidences at different spatial levels? This is why more research and international comparative studies are needed in near future.

\section{Acknowledgements}

This article was supported by the János Bolyai Research Scholarship of the Hungarian Academy of Sciences (HAS) Budapest, Hungary and Leibniz Institute for Regional Geography (IfL), Leipzig, Germany.

\section{REFERENCES}

[1] Aalbers, M. 2009: Geographies of the financial crisis. Area, 41(1): 34-42.

[2] Ahrens, J., Kelly, M. and van Liempt, I. 2016. Free movement? The onward migration of EU citizens born in Somalia, Iran, and Nigeria. Population, Space and Place, 22(1): 84-98.

[3] Angenendt, S. 2009. Labour migration management in times of recession: is circular migration a solution? Washington, Transatlantic Academy.

[4] Anthias, F. 2012. Transnational mobilities, migration research and intersectionality - towards translocational frame. Nordic Journal of Migration Research, 2(2): 102-110.

[5] Baldassar, L, and Merla, L. (eds.) 2014. Transnational families, migration and circulation of care: understanding mobility and absence in family. New York, London: Routledge.

[6] Beauchemin, C. 2014. A manifest for quantitative multi-sited approaches to international migration. International Migration Review, 48(4): 921-938.

[7] Beets, G. and Willekens, F 2009. The global economic crisis and international migration: an uncertain outlook. In Vienna Yearbook of Population Research, Venna, pp. 19-38.

[8] Bovenkerk, F. 1974. The sociology of return migration. A bibliographical essay. The Hague, Martinus Nijhoff.

[9] Brickell, K., and Datta, A. Eds. 2011. Translocal geographies: spaces, places, connections. Aldershot: Ashgate.

[10] Çağlar, A. et al. 2011. Circular migration patterns migration between Ukraine and Hungary, Metoikos Project, European University Institute Robert Schuman Centre for Advanced Studies, San Domenico di Fiesole.
[11] Çağlar, A. 2013. Circular migration between Hungary and Ukraine: Historical legacies, the economic crisis, and the multidirectionality of 'circular' migration. In: Triandafyllidou, A. Eds. Circular migration between Europe and its neighbourhood. Choice or necessity? Oxford: Oxford University Press, pp.141-165.

[12] Carlsson, T. 2017. Mobility memories and space: Mesolithic living close to the Ancylus Lake in Eastern Middle Sweden 8000 - 6000 cal BC. Sociology and Anthropology, 5(4): 332-342.

[13] Carling, J. and Erdal, M.B. 2014. Return migration and transnationalism: how are the two connected? International Migration, 52(6): 2-12.

[14] Cassarino, J-P. 2008. Patterns of Circular Migration in the Euro-Mediterranean Area: Implication for Policy-making, CARIM AS 2008/29, European University Institute Robert Schuman Centre for Advanced Studies, San Domenico di Fiesole.

[15] Castles, Stephan 2011: Migration, Crisis, and the Global Labour Market. Globalization, 8(3): 311-324.

[16] Castles, Stephan 2014: International migration at a crossroads. Citizenship Studies, 18(2):190-207.

[17] Chapman M. and Prothero, R.M. 1985. Themes on circulation in the Third World. In Prothero, R.M. and Chapman 1985. Circulation in the Third World countries. Routledge and Kegan Paul, London, Boston, Melbourne and Henley., pp.1-29.

[18] Cohen, J.H. 2017. Editorial: advancing scholarship on remittances. Remittances Review, 2(1): 1-4.

[19] Connolly, Richard 2012: The Determinants of the Economic Crisis in Post-Socialist Europe. Europe-Asia Studies, 64(1):35-67.

[20] Constant, A., Nottmeyer, O. and Zimmermann, K.F. 2013. The economics of circular migration. In: Constant, A., Zimmermann, K.F. Eds. International handbook on the economics of migration. Cheltenham, UK, Edvard Elgar, pp. 55-74.

[21] Constant, A. and Zimmermann, K.F. 2011. Circular and repeat migration: count of exits and years away from the host country. Population Research and Policy Review, (30)4: doi: 10.1007/s11113-010-9198-6.

[22] Czaika, M. Migration and economic prospects. Journal of Ethnic and Migration Studies, (41)1: 58-82.

[23] Darvas, Zs. (2011) Exchange rate policy and economic growth after the financial crisis in Central and Eastern Europe. Eurasian Geography and Economics, 52 (3): 390-408.

[24] Deshingkar P., Sharma, P., and Kumar, S. et al. 2008. Circular migration in Madhya Pradesh: changing patterns and social protection needs. European Journal of Development Research 20 (4):612-28

[25] EC, 2011. Temporary and circular migration: empirical evidence, current political practice and future optins in EU member states. Brussels: European Union - European Migration Network.

[26] Egedy, T. (2012) The effects of global economic crisis in 
Hungary. Hungarian Geographical Bulletin, 61(2):155-173.

[27] Galgóczi, B., J. Leschke, and Watt. A. 2012. EU labour migration and labour markets in troubled times. In Galgóczi, B., Leschke, J. and Watt, A. (eds.) EU labour migration in troubled times, Aldershot: Ashgate 1-44.

[28] Gödri, I., Soltész, B., and Bodacz-Nagy, B. 2014 Immigration or emigration country? Working Papers on Population, Family and Welfare, No. 19. Budapest, Hungarian Demographic Research Institute.

[29] Hárs, Á. 2014. On the characteristics of temporary transnational migration: the case of Hungary. In: Pitkäen, P., and Korpela, M. Eds. Characteristics of temporary transnational migration. Collected working papers from the EURA-NET project. Tampere: University of Tampere, pp. 136-172.

[30] Hugo, G. 2013. Migration between the Asia-Pacific and Australia. A development perspective. In: Cortina, J., and Ochoa-Reza, E. Eds. New Perspectives on International Migration and Development. New York: Columbia University Press. pp. 229-275.

[31] Illés, S. and Kincses, Á. 2017. Attempts on measurement and visualisation of international circular migration. Journal of Mathematics and Statistical Science, 3(2): 39-54.

[32] Illés, S., and Kincses, Á. 2012. Hungary as a receiving country for circulars. Hungarian Geographical Bulletin, 61(2): 197-218

[33] Jeffery, L., and Murison, J. 2011. Guest editorial, the temporal, social, spatial, and legal dimensions of return and onward migration. Population, Space and Place 17(2): 131-139.

[34] Karakayali, S. - Rigo, E. (2010) Mapping the European space of circulation. In: De Genova, N. (Ed.): The deportation regime. Durham, pp. 123-144.

[35] Kincses, Á. 2015. International migration diversity in Hungary in the 2011 population census data. Regional Statistics, vol. 5. no, 2. pp. 108-124.

[36] Kincses, Á. 2011. (ed.) Ukrán állampolgárok Magyarországon. (Ukranian citizens in Hungary.) Budapest, Printpix.

[37] King, R., and Christou, A. 2011. Of counter-diaspora and reverse transnationalism: return mobilities to and from the ancestral homeland. Mobilities, 6(4), 451-466.

[38] Kiss, É. 2012: The impacts of the economic crisis on the spatial organization of Hungarian industry. European Urban and Regional Studies, 61(2): 155-173.

[39] Lados G. and Hegedűs, G. 2016. Returning home: an evalution of Hungarian return migration. Hungarian Geographical Bulletin, 64(4), 321-330.

[40] Marcu, S. 2016. Learning mobility challenging borders: cross-border experiences of Eastern European immigrants in Spain. Mobilities, 11(3): 343-361.

[41] Massey, D.S. 2015. A missing element in migration theories. Migration Letters, 12(3): 279-299.

[42] McCollum, D. and Findlay, A. 2011. Trends in A8 migration to the UK during the recession. Population Trends 145. London, Office for National Statistics.

[43] McLoughlin, S. and Münz, R., et al. 2011. Temporary and Circular Migration. Opportunities and Challenges. Brussels, European Policy Centre.

[44] Michalkó, G., Rátz, T., Hinek, M. and Tömöri, M. 2014. Shopping tourism in Hungary during the period of the economic crisis. Tourism Economics, 20:(6) 1319-1336.

[45] Montanari, A. 2016. The building of European identity. Sociology and Anthropology, 4(7): 652-662.

[46] Newland, K. et al. 2008. Learning by Doing: Experiences of Circular Migration. Washington DC: Migration Policy Institute.

[47] Parusel, B. 2017. Circular migration and the need to define and measure it. Migration Policy Practice, 7(2): 38-43.

[48] Ratha, D. and Sirkeci, I. 2010. Editorial: Remittances and the global financial crisis. Migration Letters, 7(2), 125-131.

[49] Rátz, T, and Michalkó, G. 2013. Travel as a factor of happiness in Hungary. In: Filep, S., and Pearce Ph. Eds. Tourist experience and fulfilment: insights from positive psychology. London, New York, Routledge, pp. 54-71.

[50] Roos, C. and Zaun, N. 2016. The global economic crisis as a critical juncture? The crisis's impacts on migration movements and policies in Europe and the U.S. Journal of Ethnic and Migration Studies, 42(10): 1579-1589.

[51] Schneider, J and Parusel, B. 2015. Circular migration between fact and fiction. Evidence from Germany. European Journal of Migration and Law, 17(2-3): 184-209.

[52] Sirkeci and Cohen, 2016. Cultures of migration and conflict in contemporary human mobility in Turkey. European Review, 24(3): 381-396.

[53] Skeldon, R. 2010. Managing migration for development: is circular migration the answer? The Whitehead Journal of Diplomacy and International Relations, 11(1): 21-33.

[54] Soltész, B., Erőss, Á., and Karácsonyi, D. 2014. Hungarian cross-border migration in a fragmented ethnic space. In: Erőss, Á. Karácsonyi, D. Eds. Discovering migration between Visegrad countries and Eastern partners. Budapest: Geographical Institute, pp. 72-87.

[55] Südas, I., and Mutluer, M. 2010. Towards a better life: Lifestyle Migration. Aegean Geographical Journal 19(1): 31-47.

[56] Tilly, C. 2006 Migration in modern European history. In Messina, A.M. and Lavah, G. The migration reader. Exploring politics and policies. Boulder, London, pp. 126-146.

[57] Timothy, D.J. and Michalkó, G. 2016. European trends in spatial mobility. Hungarian Geographical Bulletin, 65(4): 317-320.

[58] Triandafyllidou, A. Eds. 2013. Circular migration between Europe and its neighbourhood. Choice or necessity? Oxford: Oxford University Press.

[59] UNECE, 2016. Defining and measuring circular migration. Prepared by the Task Force on Measuring Circular Migration, New York and Geneva, United Nations. 
[60] Vertovec, S. 2006. Is circular migration the way forward in global policy? Around the Globe, 3(2), 38-44.

[61] Weber, R. and Saarela, J. 2017 Self-selection into circular migration. Evidence from linked Finnish and Swedish register data. Stockholm Research Reports in Demography, Stockholm University, Demography Unit, Stockholm, no. 2017:28.

[62] Wickramasekara, P. 2011. Circular migration: a triple win or a dead end? International Labour Office, Bureau for Workers’ Activities (ILO ACTRAV), ILO, Geneva.

[63] Zelinsky, W. 1971. The hypothesis of the mobility transition, The Geographical Review, 61(2), 220-249.

[64] Zimmermann, K.F and Zaiceva, A. (2012) Returning home at times of trouble? Return migration of EU enlargement migrants during the crisis. Institute for the Study of Labor (IZA) Discussion Papers No.7111. , Bonn.

[65] Vertovec, S. 2013. Circular migration. In: Ness, I. (Ed.) The encyclopedia of global human migration: Vol. 2: A - Cro. Wiley-Blackwell, Chichester, pp. 1053-1058.

[66] Ács, V. 2010. Temporary and circular migration: empirical evidence, current policy practice and future options in Hungary, Budapest: European Migration Network Hungary.

[67] Illés, S. and Kincses, Á. 2009. Migráció és cirkuláció. (Migration and circulation.) Statisztikai Szemle, 87(7-8): 729-747. 